\title{
International University Students in Canada: Obtaining the Information Needed for Policy Making
}

\author{
EDWARD A. HOLDAWAY*, WENDY M. BRYAN†, \\ and WILFRED H. ALLAN $\ddagger$
}

\begin{abstract}
International university students represent sources of goodwill and benefits for their host countries. Unfortunately, Canada, although still one of the major receiving countries, has seen a substantial decline in international enrolment during the 1980s. Reasons proposed for this decline include differential fees, insufficient financial support, quotas, and employment restrictions. The problems most frequently encountered by international students in Canada involve immigration procedures, accommodation, language, loneliness, and funding.

The formulation of policies concerning these problems and other matters relevant to international university students occurs at the federal, provincial, and institutional levels. Even though the main forces driving such policies are cultural, financial, and political, the policies should take into account information about the needs, desires, and experiences of international students. A comprehensive 1986-87 University of Alberta survey of international students served as a case study to demonstrate how research can better inform policy making in this area. Respondents suggested that they would be helped by being allowed to work in Canada while studying and after graduation, which is a federal policy area, and by having more scholarships available to them and differential fees removed, both of which are provincial and institutional policy areas.
\end{abstract}

\section{RÉSUMÉ}

Les pays qui reçoivent des étudiants étrangers en retirent bienveillance et avantages. Malheureusement, bien que le Canada soit encore un des pays qui

*Dr. Holdaway is Professor of Educational Administration, (University of Alberta)

†Ms. Bryan is Research and Planning Analyst, Office of Budget and Statistics, (University of Alberta) $\ddagger$ Mr. Allan is Director of the International Centre (University of Alberta)

(Dr. Holdaway was Director of the Office of Institutional Research and Planning and Ms. Bryan was a Research and Planning Analyst in the same office when the University of Alberta survey was conducted.)

Acknowledgements. The authors gratefully acknowledge the assistance provided in preparation of this article by S. T. Carey, J. Fox, N. T. Highett, M. Laplane-Gibbons, and L. D. Vaala. 
reçoivent le plus, le nombre d'inscriptions venant de l'étranger y a considérablement diminué au cours des années 80 . Les raisons avancées pour cette baisse comprennent les droits d'inscription différentiels, l'insuffisance de l'appui financier, les quotas et les retrictions d'emploi. Les difficultés auxquelles les étudiants étrangers doivent faire face le plus souvent au Canada se rapportent au processus d'immigrations, au financement, au logement, à la langue et à isolement.

La formulation des politiques relatives à toutes ces questions et à d'autres concernant ces étudiants se fait aux niveaux du pays, de la province et de l'établissement. Ces politiques se fondent surtout sur des motifs culturels, économiques et politiques. Elles devraient toutefois tenir compte des besoins, des désirs et de l'expérience des étudiants étrangers. Une enquête détaillée menée auprès des étudiants étrangers par l'Universté de l'Alberta en 1986-1987 a servi pour d'étude de cas pour démontrer comment la recherche peut aider à éclairer les responsables de l'établissement des politiques. Dans cette enquête, les intéressés ont fait savoir qu'il leur serait utile d'avoir la permission de travailler au Canada pendant leurs études et après l'obtention de leur diplome, ce qui est une politique établie au niveau fédéral. Ils désireraient aussi avoir accès à davantage de bourses et voir annuler les frais differentiels, ce qui relève des provinces et des établissements.

Those who work in Canadian universities are aware of the presence on their campuses of considerable numbers of students from other countries. These "international students," i.e., those who hold a valid Canadian Immigration Student Authorization and are neither Canadian citizens nor permanent residents, comprised $5 \%$ of the total university enrolment in Canada in 1986 (Simard and Hockin, 1986). Their total enrolment was 27,655 students in 1986-87 (Canadian Bureau for International Education, 1988). "Foreign students" and "overseas students" are used synonymously for "international students." This article examines the function of data in policy development relevant to the international student situation in Canada, using information obtained from a 1986-87 survey conducted at the University of Alberta to demonstrate this relationship.

Important policy questions concerning international university students exist at the federal, provincial, and individual university levels. Fox, Humphries, and Lewis (1987) noted that "in the past two years both senior levels of government have initiated policy reviews regarding international students in Canada," and then identified the following examples of policies made at the three levels (p.5). Federal policies govern immigration requirements, employment, some scholarships, and taxation. Provinces are involved in the development of policies concerning fee differentials, eligibility for provincial awards, health insurance, education of dependent children, and legal aid. Also, both federal and provincial governments are able to set policies regarding whether they would transfer funds to 
support the "add-on" costs of international students. Universities can establish policies with respect to quotas for-international students in different faculties, admissibility including language requirements, the provision of financial and other support, and possibly the introduction of fee differentials depending on the nature of relevant provincial policy. In this regard, "policy" usually consists of official statements which affect the behavior of various groups of people. The means by which policies are translated into regulations and procedures is an important and separate topic.

In Canada, little relevant data now exist to guide formulation of policies about international students at the three levels. Consequently, policies are developed and approved by various federal, provincial, and institutional bodies largely in the absence of comprehensive, relevant data. Ad hoc studies are occasionally conducted in a short-time frame to address a particular matter which is viewed as urgent for political, financial, or other reasons. After conducting a comprehensive review of the international literature on the research-policy relationship, Holdaway (1986) concluded that although policy makers are usually influenced more by social, economic, and political considerations and by personal sentiments than by research findings, research can contribute to policy making by "clarifying issues, providing data, sensitizing policy makers, and providing conceptual analyses," and that "policy makers in a wide variety of arenas are requesting that more research be conducted to assist them" (pp. 258-259). Both McDonald (1976, pp. 1-2) and Coleman and LaRocque (1983, pp. 247-248) advocated that, if research is to affect policy, then the research design should specifically address the concerns of policy makers and incorporate the policy alternatives. Although policy decisions are rarely "data-driven," more data are obviously needed in order to ensure that decisions about international university students in Canada are at least "data-assisted."

Development of sound policies in this area is extremely important because the implications of the attendance of international students at Canadian universities are substantial, with far-reaching consequences. This sentiment was well expressed by the Report of The Special Joint Committee on Canada's International Relations entitled Independence and Internationalism (Simard and Hockin, 1986):

We believe that foreign students constitute an important asset for Canada that has not been sufficiently recognized in terms of improving trade opportunities, increasing cultural contacts and more generally for foreign policy. Foreign students could, on their return to their countries of origin, be hired to represent Canadian firms, bringing advantages to both sides. (p. 96)

International students, once they return to their home countries, may hold influential positions in foreign governments, may staff hospitals, schools and universities, and may be managers in major corporations and agencies. These individuals are seen to "comprise a kind of intangible global matrix of cultural, collegial, commercial and personal ties which produces enormous tangible benefits for Canada" (Canadian Bureau for International Education, 1986, p. iii). 
In addition to these benefits which may accrue as a result of international education, students' sojourns in foreign countries provide many benefits to the universities at which they study and the communities in which they reside. These benefits have been described by the Canadian Bureau for International Education in two separate publications:

The universality of knowledge and the need for international cross-fertilization of scholarship are principles fundamental to the university. In an increasingly inter-connected world, young Canadians should be given the opportunity to work with and to understand people from other cultures and countries.... The presence of foreign students in Canadian colleges and universities can help to make it possible. (Canadian Bureau for International Education, 1977, pp. $1-2)$

Foreign students are a resource for the educational community, as they bring with them a variety of experience unknown to most Canadians. More tangibly, foreign students in graduate programmes provide both skilled manpower and valuable international links to research projects. (Canadian Bureau for International Education, 1981, p. 40)

Therefore, Canadians should feel obliged to provide first-rate education and positive cultural experiences for international students.

However, enrolments of international students in Canadian universities are declining. From an all-time high of 36,074 in 1982-83, the number dwindled to 27,655 in 1986-87. This decline occurred at a time when total student enrolments in Canadian universities were increasing (Figure 1) and other countries continued to have rising enrolments of international students (Canadian Bureau for International Education, 1986).

Various reasons have been proposed for this decline in enrolments of international students in Canadian universities, but the imposition of differential fees has been identified as the major reason (Simard and Hockin, 1986; Canadian Bureau of International Education, 1986). Other factors include "limited scholarship assistance, ... program restrictions, enrolment quotas, restrictions on employment, and the costs of accommodation, health care and other services" (Canadian Bureau for International Education, 1986, p. i). In spite of this decline, in 1986 Canada still ranked among the top five receiving countries for international students along with France, Germany, the United States, and the United Kingdom (Simard and Hockin, 1986). The top three countries sending international students to Canadian universities in the 1980s have been Hong Kong, Malaysia, and the United States. In the early 1980s, these countries accounted for over $50 \%$ of all international students in Canada, but that percentage had dropped to $42 \%$ by 1986 . The decrease in the proportion from the top three countries was the result of an absolute decrease in the enrolments of their students rather than an increase in the enrolments of students from other countries. The drop in enrolments of Malaysian students was greatest. From a high of 5,633 students (16\% of international enrolment) in 1982-83, enrolments of Malaysian students declined to only 1,501 $(5.6 \%)$ in 1986-87. Twenty-five of the "least developed" countries continue to send less than $3 \%$ of the international students in Canada, as they have throughout the 1980s (von Zur-Muehlen, 1987). 


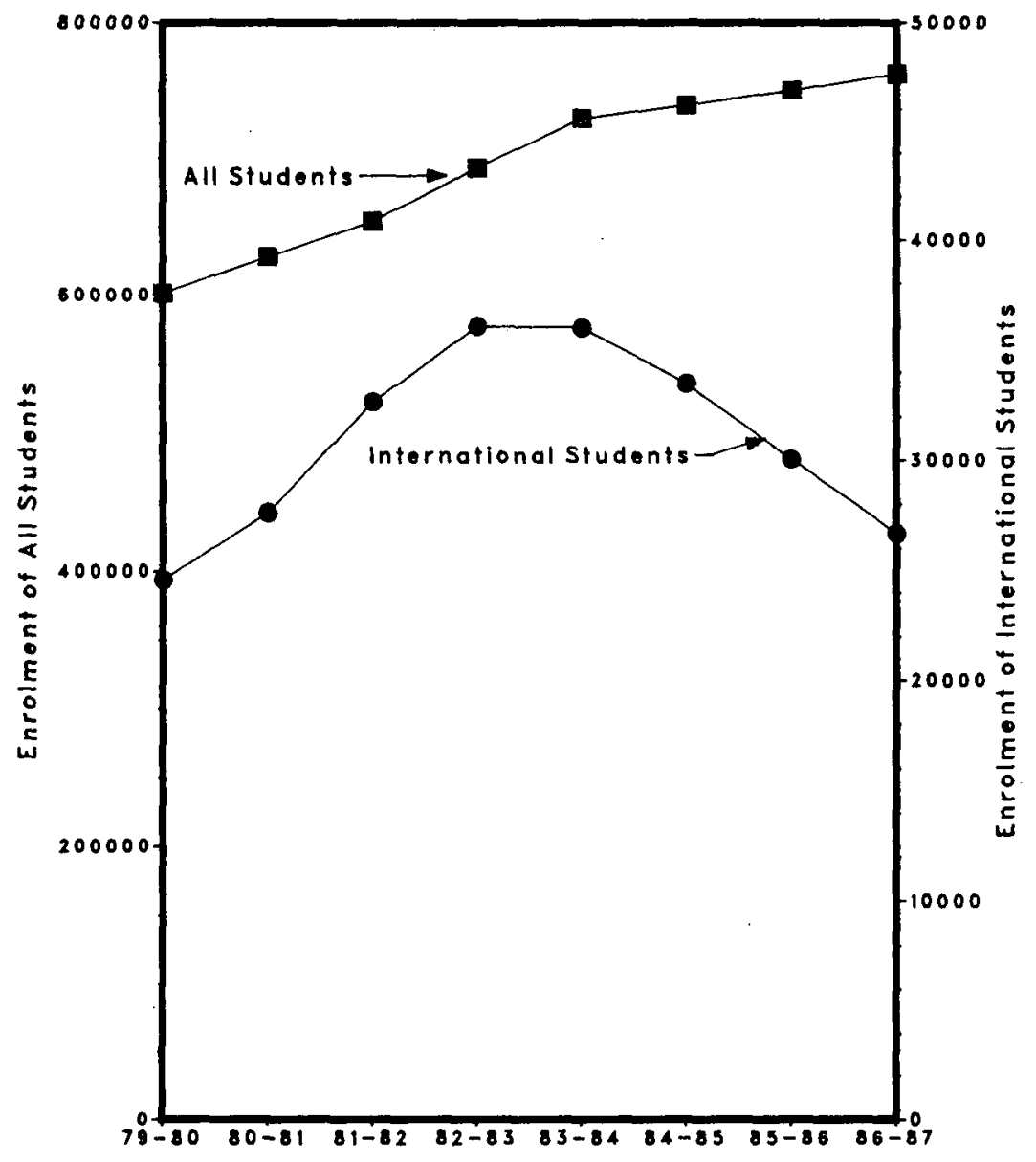

Figure 1. Total University Enrolments of International Students and All Students in Canada, $1979-80$ to $1986-87$

Sources of Statistics:

(a) Conadian Higher Education Research Network Working Papers 85.1 and 87.2

(b) Statistics Canada-

Education in Canoda: A Statistical Review for 1983-84 \#81-229 Advance Statistics in Education 1986-87\#81-220

The other statistics about international students in Canada which are commonly available include sex, level of study (undergraduate, graduate), and place of study. In 1979-80, only $31 \%$ of international university students were female, but this increased on an average of $0.74 \%$ per year, reaching $36.2 \%$ in $1986-87$. While Canadian graduate students constituted a fairly steady $12 \%$ of Canadian 
enrolments in the $1980 \mathrm{~s}$, international graduate students comprised a third of international enrolments, with that proportion rising in recent years.

Although the national and university statistics presented are both interesting and useful, they also serve to point out the limited amount of information that is readily available and the gaps in existing knowledge. For some time, more research has been needed in many aspects concerning international students. The Council of Ministers of Education of Canada succinctly stated this need in its report Foreign Students in Canada (1986):

Every study carried out on foreign students in Canada has lamented the inadequacy of information on the numbers, origins, distribution, personal characteristics, socio-economic background, finances, activities, and costs of foreign students in this country. Although in recent years, access to basic data has improved substantially, there remain a number of difficulties in obtaining reliable information. Without accurate, up-to-date information on a range of factors, policy makers run the risk of reaching decisions that are based more on opinion than on facts. (p. 6)

\section{RESEARCH FINDINGS}

Research about international students has been conducted at individual universities, e.g., The University of Toronto (1986), Queen's University (Myles, 1987), and The University of New South Wales, Australia, (Burke, 1986). Sometimes specific groups are studied, as exemplified by Mickle and Chan's (1986) research on Hong Kong Chinese students in Canada. A national perspective has been taken by other researchers, e.g., in Britain by Williams, Woodhall, and O'Brien (1986) and in the U.S. by Zikopoulos (1986). Still others have used an international perspective, e.g., Klineberg and Hull (1979) and Deutsch (1970). Questionnaires were the most common data-collection instrument, with interviews being used far less frequently. The data presented below are taken from these studies; information from other sources is also included where appropriate.

\section{Personal Characteristics}

The information presented below on sex and marital status, country of origin, and age has relevance to policy decisions in Canada and the home countries, and may have implications for discussions on possible changes in these policies.

Sex and marital status. At the University of Toronto in the mid-1980s, $63 \%$ of the foreign students were males, $12 \%$ were married, $76 \%$ of the married students had their spouses with them, and $46 \%$ of those with children had them living with the student. Similarly, at the University of New South Wales in 1986, 68\% were males and $3 \%$ were married. In the 1986 British study, $74 \%$ were males and a much higher proportion $(37 \%)$ were married than at Toronto or New South Wales, with only $12 \%$ having their spouse with them. The 1986 U.S. study reported that $71 \%$ were male and $20 \%$ were married. Of the Hong Kong Chinese undergraduate students in Canada in 1986, a lower proportion (52\%) were male, and $4 \%$ were married. 
Country of origin. At the University of Toronto, the most common countries of origin were Hong Kong (36\%), Malaysia (7\%), China (3\%), and India (2\%), whereas at the University of New South Wales, $62 \%$ were from Malaysia, $20 \%$ from Hong Kong, and 9\% from Indonesia. The leading countries of origin in the U.S. study were Taiwan (7\%), Malaysia (7\%), Republic of Korea (5\%), India $(5 \%)$, and Canada (5\%), in the British study, Hong Kong (11\%), Malaysia (9\%), Nigeria (9\%), and the U.S. (7\%) were the major countries. Obviously, the distribution by country is dependent upon factors such as geographical proximity, wealth, and traditional linkages.

Age. The research on Hong Kong Chinese undergraduate students in Canadian universities showed that $92 \%$ were 25 or younger, while the University of New South Wales and British figures were $96 \%$ and $58 \%$. Differences in age are obviously associated with levels of study, i.e., the proportional representation of undergraduate and graduate students.

\section{Academic Characteristics}

The academic level of international students varied depending on the country or institution in which the students were studying. For example, at the University of Toronto, undergraduates comprised $62 \%$ of survey respondents and graduates $38 \%$, whereas at Queen's University, undergraduates outnumbered graduates by only $53 \%$ to $47 \%$. In the United States in 1985-86, 59\% of foreign students were undergraduates and $41 \%$ were graduates; these percentages are close to the averages for the two Canadian universities. However, in Britain, $33 \%$ of university-level overseas students in 1985 were studying for their first degree, $53 \%$ were at the graduate level, and $14 \%$ were enrolled in other programs.

Certain programs of study have been more popular for foreign students. Engineering attracted $25 \%$ of the students in Britain, $22 \%$ in the United States, and $33 \%$ at Queen's. Business was studied by $25 \%$ of the students in Britain and $19 \%$ in the United States. Ten percent of foreign students in the U.S., 12\% at Queen's, and $5 \%$ in Britain studied mathematics and computing science.

The primary activity of foreign students prior to their current programs of studies may affect both satisfaction with preparation for current studies (Mickle \& Chan, 1986) and establishment of positive cross-cultural contact (Klineberg \& Hull, 1979). In Britain in 1985, 36\% of overseas students had been working and $58 \%$ had been in full-time education in the year prior to the survey.

\section{Reasons for Studying Away From Home Country}

Numerous reasons have been suggested as motivation for study abroad - study in a foreign country as a preliminary to emigration, lack of domestic facilities, inability to obtain admission at home, desire to improve professional opportunities at home, and opportunities for linguistic training, cultural enrichment, and experience of living in another environment (Lulat \& Altbach, 1985). Once the decision has been made to study abroad, the next decision concerns choice of institution. The 
most important reason for foreign students at the University of Toronto was the quality and reputation of the university $(48 \%)$; the second most important factor was the recommendation of family, friends, or teachers $(23 \%)$. In Britain, quality of education ( $40 \%$ ) and financial incentive (13\%) were important. In Australia, the reputation of the university and its degrees $(48 \%)$, ease of obtaining entry $(31 \%)$, the quality and range of available facilities (29\%), and attendance at the University by family and friends $(25 \%)$ were rated highly.

\section{Financial Aspects}

How to finance their education is often a crucial question for students wishing to study in Canada. The University of Alberta International Centre estimates that a year's study in Edmonton costs about $\$ 7,600$ in addition to fees. Canada Employment and Immigration requires that a student from overseas provide proof of ability to pay before being granted a Student Authorization. Most of the money (74\%) used by students came from outside Canada through personal savings, family and friends, or non-Canadian scholarships (Shore, 1986). Income from family and friends was the most frequently reported source of funds in different studies. Other sources reported in Toronto included fellowships, scholarships, or bursaries (46\%); income from employment, research assistantship, or teaching assistantship (21\%); government or institutional loans $(20 \%)$; and personal savings $(16 \%)$.

Most foreign students in seven of the ten provinces in Canada pay higher tuition fees than do domestic students. These higher fees have been seen as contributing to the decline in international enrolments in Canada (Simard \& Hockin, 1986; Canadian Bureau for International Education, 1986). Although overseas students at the University of New South Wales did not object in principle to paying higher fees, almost two thirds of them reported that it was "hard" or "very hard" to find the money to pay the Overseas Student Charge (Burke, 1986).

\section{Problems Faced by International Students}

Weston (1986) has noted that foreign students face a "multiplicity of problems" ( $p$. 2). These problems can be associated with the five stages in student flow: pre-arrival, arrival and orientation, study, departure, and post-departure (Council on Student Services, 1986, pp. 3-12). Such problems include pre-arrival difficulties in obtaining a Student Authorization and getting adequate financing, orientation problems in finding one's way in a new environment and locating adequate accommodation, and study difficulties such as speaking and writing English and coping with different teaching methodologies. Social problems such as loneliness, making friends with the local people, and discrimination may also be experienced. Loneliness and homesickness have been noted as problems for students in the U.S. (81\%) (Deutsch, 1970) and in Britain (49\%) (Williams et al., 1986; Williams, 1987). These problems tend to decrease over time. 


\section{Perceptions and Use of Facilities and Services}

The various facilities and services which are available to foreign students have tended to be utilized by relatively few of the students. Those students that did attend or use the various facilities or services tended to perceive them as helpful. In Britain, $69 \%$ of participants perceived orientation to be useful, and various counselling services were rated as "very" or "fairly helpful" by $84-94 \%$ of the students. Extra assistance with English was rated as "very" or "somewhat helpful" by $83 \%$ of the students at the University of Toronto.

\section{Social Experiences}

Klineberg and Hull (1979) suggested that "those foreign students who are satisfied and comfortable with their interactions with local people and the local culture during their sojourn would report broader and more general satisfaction with their total sojourn experience" (p. 53). They found that 53\% of the foreign students in Canada reported that their contact with local people was less than what they wanted.

\section{Future Planning}

Of the university and polytechnic respondents in Britain, $27 \%$ planned to continue studying in Britain, and $8 \%$ wanted to find a job there. More (44\%) planned to return home and work than to undertake any of the other choices. A further $13 \%$ were planning studies elsewhere, $9 \%$ at home, and $4 \%$ in another country.

Host countries may have plans which include increased opportunities for international education. Canada's thrust for improvements is evidenced by the push for a national policy on international students, the inclusion of submissions on the subject of foreign students to the Special Joint Committee on Canada's International Relations (Simard \& Hockin, 1986), and the ongoing work of the Canadian Bureau for International Education which "promotes international development and intercultural understanding through a broad range of educational activities and programs in Canada and abroad" (McBride, 1983, p. 1).

\section{UNIVERSITY OF ALBERTA SURVEY}

\section{Background}

The University of Alberta's International Student Policy adopted in 1986 states that "The University of Alberta has long had a tradition of welcoming students from other countries. They make a substantial contribution to the entire University community. The value of a university education is enriched and broadened by an international perspective" (General Faculties Council, 1986). Some of the University's enrolment objectives are as follows:

1. To strive for student representation from as many countries and cultures and in as many fields of study as possible. 
2. To have sufficient international students to make a significant impact on undergraduate and graduate programs including quota faculties and to monitor enrolment in this regard.

3. To actively encourage the selection of students from less developed countries through scholarships and other financial support.

Enrolments of international students at the University of Alberta ( $U$ of A) continued to rise until $1983-84$, peaking at 1,655 full-time students, $7.0 \%$ of total full-time enrolment. Decreases have occurred every year since then; the total of 1,553 international students in $1986-87$ was $6.4 \%$ of the total enrolment, $3.8 \%$ of the total undergraduate enrolment, and $26.5 \%$ of the total graduate enrolment. In terms of enrolments of international students, the $U$ of $A$ ranked fourth among Canadian universities, but eighth in terms of percentages of full-time enrolment. Prior to 1969 , the country sending the largest number of international students to the $U$ of $A$ was the United States with over $17 \%$ of the international students. Since 1969 Hong Kong has been the top sender, with $32.4 \%$ of international students at the U of A in 1986-87. The People's Republic of China became the second largest sender in $1986-87$ with $10.6 \%$, followed by Malaysia (5.3\%), India (5.1\%), England (4.4\%), and the United States (4.3\%). Enrolments of international graduate students at the $\mathrm{U}$ of $\mathrm{A}$ as a proportion of all international students rose from $36.1 \%$ in $1979-80$ to $47.1 \%$ in $1986-87$. This was substantially higher than the national proportion of international graduate students which has remained fairly steady around $35 \%$.

Two financial matters directly relate to international students - fees and student awards. First, at the $\mathrm{U}$ of $\mathrm{A}$, students who are not Canadian citizens or permanent residents ("landed immigrants") are assessed a differential fee of an additional $50 \%$ of all instructional fees. That is, full-time international students in 1986-87 were required to pay $150 \%$ of either the undergraduate instructional fee for an eight-month Winter Session of \$876 (Engineering \$1,106; Dentistry \& Medicine $\$ 1,318$ ) or the graduate instructional fee of $\$ 1,100$. (The graduate programs had "total instructional fees" or "program fees" assigned to them; for example, a 3-year $\mathrm{Ph} . \mathrm{D}$. program fee consists of three payments of $\$ 1,100$ at $1986-87$ rates. Continuous registration fees were paid if attendance goes beyond the specified time period. These were $\$ 44$ per term and were also assessed the $50 \%$ differential.) "General fees" (e.g., students" union and athletic services) and "other fees" (e.g., fees for additional and audited courses) were not subject to the differential. Second, international students were ineligible to apply for many student awards. For example, international graduate students were specifically excluded from those eligible to hold some provincial awards, e.g. the 60 Province of Alberta Graduate Fellowships and Scholarships. The major university sources of support for international graduate students were teaching or research assistantships. However, some may not have been considered suitable to hold teaching assistantships because of difficulties associated either with English or with various aspects of the content of courses to which they could have been assigned. 
$\mathrm{U}$ of A policy in 1986-87 required that undergraduate and graduate students whose native language is not English must achieve TOEFL scores of 600 and at least 550 before they are admitted. Some exemptions were granted, especially for those students who had received prior education in Canada.

Several research reports on $U$ of $A$ international students have been produced, and these were influential in the decision to establish an International Student Centre which opened in 1984. This Centre has provided a useful focus for consideration and handling of relevant issues. Earlier concerns about overrepresentation of students from some countries, especially SE Asia, and concentration of international students in some faculties such as Engineering, have been replaced by broader considerations, especially concerning the lack of information for institutional policy making. For example, the Council on Student Services (1986) made these two recommendations:

Since information on international student progress and outcomes is not readily available, it is recommended that annual statistics comparing various groups of international students and Canadian students be provided by Institutional Research and Planning [IRP]. (p. 16)

Since international students from different parts of the world differ in their perceptions and requirements, it is recommended that IRP encourage and facilitate case studies and follow-up surveys of major national student groups. (p. 16)

IRP was able to produce the statistics requested in the first recommendation; this information was sent to the Registrar for distribution at his discretion. The second recommendation prompted the Dean of Student Services to request that IRP undertake a survey of international students at the University of Alberta in 1986.

\section{Objectives and Design}

The main objectives of the 1986-87 University of Alberta Survey were as follows:

1. To describe the personal and academic characteristics of international students at the University of Alberta.

2. To probe students' perceptions of problems that they have experienced.

3. To investigate students' perceptions and use of facilities and services designed to be used by international students.

4. To identify areas in international students' experiences where improvements may be made.

In order to obtain replies from many students, the decision was made to send a specifically designed questionnaire to all $\mathrm{U}$ of $\mathrm{A}$ international students. Initially, questions were developed based upon important areas identified either in the literature reviewed above or by relevant $\mathrm{U}$ of $\mathrm{A}$ officials. These questions related to both policy considerations and aspects of general interest. Special attention was paid to matters of expression and interpretation associated with different cultural backgrounds and language skills. Questions and format used in earlier IRP surveys provided the skeleton of the questionnaire. Some of the personal characteristics 
were available from central sources such as university data bases and immigration reports, but they had to be included in the questionnaire in order to facilitate analyses by sub-groups in the population while maintaining anonymity of the respondents. The questionnaire was pilot-tested with a sample of 25 students, 11 of whom responded. It was then modified and the new version was discussed with a stratified representative sample of 10 international students. The questionnaire was again revised to incorporate their suggestions, including (a) revised wording to remove ambiguity, to use appropriate language, to clarify meaning, and to ensure completeness, and (b) addition of some items. In its final form, the 12-page questionnaire consisted of 40 questions, most of which required selection of an answer from provided categories while a few were free-response. After making some minor modifications suggested by the U of A General Policy Committee on Human Research, IRP mailed the questionnaire and a campus mail return envelope to either the home or U of A addresses of 1,577 students on 11 December 1986; those in the pilot population of 25 and those with no Edmonton-area address were excluded. A follow-up letter was sent on 8 January 1987. Anonymity was guaranteed, and neither the questionnaires nor envelopes had any identifying marks or numbers. Canada Post returned 32 as undeliverable, and three completed questionnaires were returned after the analyses had been finalized. The total number of usable returns was 797 , which was a return rate of $51.6 \%$ based upon 1,545 possible returns $(1,577$ minus 32$)$. This rate was approximately the same as IRP had obtained in other student surveys.

In order to assess the extent to which the respondents were representative of the population of 1,545 , the sample and population were compared with respect to sex, undergraduate-graduate proportions, age, program, and country of citizenship. The only substantial difference was that a greater proportion of the respondents were graduate students $(59 \%)$ than were in the population (49\%) at the time of the study. Thus a bias towards graduate students exists in the data.

The respondents provided a great deal of interesting and useful information. Most of that presented here relates to policy issues. However, a brief picture of the respondents is desirable and is presented first; it reinforces and expands upon information provided earlier. Females constituted $44 \%$ and $24 \%$ of the undergraduate and graduate respondents. Students from 74 of the 91 represented countries responded; they spoke 72 different languages or dialects. Half of the graduate students and $7 \%$ of the undergraduates were married. The departments with the most international students were Chemistry ( $7.5 \%$ of the respondents), Computing Science $(6.5 \%)$, Economics (5.4\%), Civil Engineering (5.1\%), and Electrical Engineering ( $5.0 \%$ ). The main activity of the 329 responding undergraduates prior to studying at the $\mathrm{U}$ of $\mathrm{A}$ was either studying at another Canadian postsecondary institution (44\%) or studying at a Canadian secondary school (37\%). In contrast, $49 \%$ of the 465 responding graduates had been employed prior to starting their $U$ of A studies, $29 \%$ were studying at a postsecondary institution in their home country, and only $12 \%$ were studying at another Canadian postsecondary institution. Undergraduates identified parents or guardians as the main source of their funds, 
while graduates identified employment, usually graduate assistantships. Involvement in student clubs was reported by $41 \%$. Those most likely to be subject to loneliness and undue stress were females, younger students, married students separated from their spouses, and students from the People's Republic of China.

Some generalized findings relevant to national policies were as follows:

1. A substantial percentage (59\%) experienced problems in obtaining a Student Authorization. One student described his worrying experience in this way:

Getting a Student Authorization and a Work Permit was my biggest problem. The Canadian Embassy in my home country made several mistakes, so that although I had applied for these papers well in time-I didn't get them until the day before I had to leave my home country. Therefore, until the last day I didn't know whether I could go to Canada or not.

2. Over two thirds of the respondents selected "very important" for the propositions that (a) more scholarships and awards for study in Canada be provided $(71 \%)$ and (b) that international students be allowed to work while here either during study or for a short time after graduation (69\%).

3. Over half (53\%) saw as "very important" allowing spouses to work while here.

4. About $11 \%$ hoped to apply for permanent resident status after completing their current degree programs.

The major finding relevant to provincial policy was that $72 \%$ viewed removal of differential fees as "very important." About 60\% answered "very important" (31\%) or "somewhat important" $(29 \%)$ to the possibility that scholarships be provided to do thesis research in the home country; this could relate to federal, provincial, or university policy. Also, $49 \%$ considered that provision of more opportunities for exchange scholars was "very important"; this too could involve policies at all three levels.

Several problems and suggestions identified by the responding international students related to $U$ of A policies and practices, as well as to the students' experiences at the U of A. As could be expected, some had these difficulties: (a) passing the TOEFL and other admission tests; (b) financing their travel and studies; (c) coping with stress, family separation, and loneliness; and (d) arranging accommodation. The long time taken for return mail to arrive was a commonly mentioned problem. In general, the graduate students experienced less difficulty with most areas than did the undergraduates except for having sufficient money to meet expenses. Most respondents were unfamiliar with many of the facilities and services available on campus, but did consider that useful additional activities would be workshops on resume writing, job searches, and job interviews (50\% of respondents), allowing home-country recruiters to interview on campus $(45 \%)$, and matching international students with assisting Canadian students $(42 \%)$.

When asked to identify the main reason for choosing the U of A, 24\% of the respondents chose its quality and reputation, 23\% the availability of desired program, 23\% the cost relative to other Canadian universities, and $20 \%$ the scholarship, assistantship, or other financial incentive. Graduate students placed 
far more importance upon financial incentives, availability of research facilities, and reputation of particular professors, while undergraduates emphasized relative costs and friends or family support nearby.

\section{DISCUSSION}

The results of this survey of international students revealed high overall levels of satisfaction with the opportunity to study in Canada and at the University of Alberta. That is, these students were generally pleased with their experience and were grateful for the opportunity, but they did identify several areas in which policy and practice could be improved. The findings tended to be similar to those obtained in the studies reported earlier.

This survey can be viewed as a case study from which the $U$ of $A$, other universities, and federal and provincial governments and agencies can become better informed about relevant issues. The $U$ of A survey generated information about its international students which could help in policy decisions as well as in making the university community more knowledgeable. Although the information was obtained from international students who were attending one particular university in Canada, it should have relevance to the situations in other Canadian universities. Other universities could use similar methodology; our only suggestion for change would be the possible inclusion of either concurrent or consequent interviews to add more insight. Use of the population of international students for questionnaire distribution rather than a sample is desirable in order to contact (a) all students on a topic which directly affects them and (b) students from countries which have small representation. A great deal of goodwill was generated just by the conducting of the survey, although we should report that some international students, perhaps because of their home-country experiences, were apprehensive about completing the questionnaire despite guarantees of anonymity.

Several consequences resulted from the $U$ of A survey. First, the Dean of Students, as Chairman of the Council on Student Services, asked a task force to report to the Council with recommendations based on the survey findings and meetings with groups of international students. Second, the Office of Public Affairs emphasized the aspect of loneliness in one of its publications; this resulted in sixteen media stories (radio, TV, and print) which increased the awareness of many people about this matter. Third, because cross-cultural counselling was identified as an area of concern, a Nigerian doctoral student is examining this function and will be making recommendations to the Director of the International Centre. Fourth, the survey results added impetus to the process to create the International Centre and to relocate it in the HUB International building, which was renamed to add "International." Fifth, the desire of international students to have more contact with Canadians was accommodated by instituting different programs which bring together both Canadian and international students every noon hour during the winter session. Sixth, following the sharing of the U of A Report with Canada Employment and Immigration (CE\&I) officials, the U of A was designated as the centre for a pilot project involving the installation of a CE\&I 
terminal and printer which will allow immediate printing and issuing of official CE\&I documents in the $U$ of $A$ International Centre. These six consequences related to $\mathrm{U}$ of $\mathrm{A}$ and federal actions; no obvious consequences have yet occurred at the provincial level.

Soon after this U of A survey was completed, the Canadian Minister of Employment and Immigration (Benoit Bouchard) on 24 February 1988 announced the following changes in the regulations affecting employment of international students and their spouses:

Foreign students in the following groups may be granted permission to accept work without the job needing validation or being subject to the availability of Canadians:

- students working on-campus;

- spouses of students;

- students working after graduation in education-related jobs for up to 12 months; and

- students in Canada under the auspices of the Canadian International Development Agency.

There is little doubt that these welcome changes were heavily influenced by expressions of opinion, similar to those in this survey, which had been made over several years. Mr. Bouchard also stated that Canada recognizes the "economic, academic and social contributions these students make to our country." The announcement was "part of an overall federal government strategy to create a positive atmosphere for international students in Canada" and mentioned that "federal and provincial governments are continuing to work together to improve the environment for international students."

Also, the sponsorship by the Secretary of State of a national survey of international students to be coordinated by the Canadian Bureau for International Education (CBIE) was announced at the November 1987 CBIE Conference in Quebec City. It is being conducted jointly by staff of both CBIE and Carleton University, using a stratified sample of 20 universities. The survey questionnaire was based upon that used at the University of Alberta. Data from the survey will allow for development of a national picture of the international student situation and a better data base, as well as for provision of regional information and comparisons among regions. These data will also assist federal politicians and officials when they are considering changes to policies and practices which affect international students across Canada. However, because this national study could not include all of the questions relevant to provincial and institutional policies, individual universities may wish to conduct their own additional supplementary surveys.

Other relevant research projects could be undertaken. For example, various types of economic impact studies could be conducted in Canada and the countries from which our international students come. Another important category of studies could examine the reasons why qualified students wishing to come to Canada have not come and in particular whether financial constraints were 
predominant. This is related to the issue of possible provision of additional funding to allow married students to bring some or all of their family members, so that the crucial aspect of reduction of loneliness can be at least partially overcome.

As pointed out earlier, most policy decisions are more likely to be data-assisted than data-driven. For example, provincial governments will probably decide their policies on differential fees more on the basis of their perceptions of attitudes of their electorates and the need to raise extra revenue than on the opinions of international students concerning whether tuition fees are equitable and the possibility that removal of differential fees would attract more international students. However, the opinions of students relevant to policy decisions should always be sought even though other considerations will probably predominate. Cooperative effects at the federal, provincial, and institutional levels appear to present the best means of ensuring that as much relevant information as possible is collected about this important and complex topic.

\section{REFERENCES}

Bryan, W. M., Holdaway, E. A., \& Allan, W. H. (1987). Survey of International Students. 1986-87. Edmonton: Office of Institutional Research and Planning, University of Alberta.

Burke, B. D. (1986). Experiences of overseas undergraduate students. Student Counselling and Research Unit Bulletin, No. 18. Kensington, NSW: The University of New South Wales.

Canadian Bureau for International Education. (1977). A question of self-interest. A statement on foreign students in Canada. Ottawa: Author.

Canadian Bureau for International Education. (1981). The right mix: The report of the commission on foreign student policy in Canada. Ottawa: Author.

Canadian Bureau for International Education. (1986). Closing the doors? A statistical report on international students in Canada. 1983-85. Ottawa: Author.

Canadian Bureau for International Education. (1988). The national report on international students in Canada, 1986-87. Ottawa: Author.

Coleman, P., \& LaRocque, L. (1983). Linking educational research and educational policy via policy-relevant research. The Alberta Journal of Educational Research. 29(3), 242-255.

Council of Ministers of Education, Canada. (1986). Foreign students in Canada. Vol. 1. A statement of issues for policy consideration. Toronto: Author.

Council on Student Services. (1986). Services available to international students. Standing Committee on Student Services reports and reviews. Report No. 3. Edmonton: Council on Student Services, University of Alberta.

Deutsch, S. E. (1970). International education and exchange. Cleveland: The Press of Case Western Reserve University.

Fox, J., with Humphries, J., \& Lewis, B. (1987). Where to now? Ottawa: Canadian Bureau for International Education.

General Faculties Council. (1986). Policy Manual (Section 108.11). Edmonton: University of Alberta. Holdaway, E. A. (1986). Making research matter. Alberta Journal of Educational Research. 32(3), 249-264.

Klineberg, 0., \& Hull, W. F. (1979). At a foreign university: an international study of adaptation and coping. New York: Praeger.

Lulat, Y. G.-M., \& Altbach, P. G. (1985). International students in comparative perspective. In J. C. Smart (Ed.), Higher education: Handbook of theory and research. Vol. 1. New York: Agathon Press, pp. 439-494.

McBride, J. R. (1983). Annual Report 1983. Ottawa: Canadian Bureau for International Education. 
International University Students in Canada:

McDonald, J. (1976, April). Designing research for policy making. Paper presented at the Annual Meeting of the American Educational Research Association, San Francisco.

Mickle, K., \& Chan, R. (1986). The cross cultural adaptation of Hong Kong Chinese students at Canadian universities. Ottawa: Canadian Bureau for International Education.

Myles, W. (1987). A study of international students at Queen's University 1976/77-1985/86. Kingston: International Centre, Queen's University.

Shore, V. (1986). Foreign students bring great benefits. University Affairs, January, p. 40.

Simard, J.-M., \& Hockin, T. (1986). Independence and internationalism. Report of the Special Joint Committee on Canada's International Relations. Ottawa: Queen's Printer, pp. 94-97.

Statistics Canada. (1984). Education in Canada: A statistical review for 1983-84. (Catalogue 81-229.) Ottawa: Minister of Supply and Services Canada.

Statistics Canada. (1986). Advance statistics in education 1986-87. (Catalogue 81-220). Ottawa: Minister of Supply and Services Canada.

University of Toronto. (1986). Report of the presidential task force on foreign students. Toronto: Author.

von Zur-Muehlen, M. (1987). International students in Canada: A statistical portrait of the mid-1980s. Ottawa: Canadian Higher Education Research Network Working Paper 87.2.

Williams, E. (1987). Loneliness of foreign students. Times Higher Education Supplement. 7 August, p.4.

Williams, G., Woodhall, M., \& O'Brien, U. (1986). Overseas students and their place of study. London: Overseas Students Trust.

Zikopoulos, M. (1986). Open doors: 1985/86. Report on international educational exchange. New York: Institute of International Education. 